\title{
Effect of Mixture Composed of Jeju' Scoria and Ecklonia cava on Anti-inflammation
}

\author{
Hyun Kang ${ }^{\dagger ; *}$ \\ Department of Medical Laboratory Science, College of Health Science, Dankook University, \\ Cheonan-si, Chungnam 31116, Korea
}

The purpose of this study is to investigate the anti-inflammation effect of the mixture, consisting of a series of different ratio of Ecklonia cava extract and scoria. Also, to make more functional scoria powder into cosmetic material, studies on the toxicity by cell viability assay. Scoria is found in large amounts in Jeju Island, as an adsorbent of heavy metal ions $\left(\mathrm{Ni}_{2}+, \mathrm{Zn}_{2}+\right.$, and $\left.\mathrm{Cr}_{3}+\right)$ in an aspect of its efficient utilization. Marine plants such as Ecklonia cava contain high amounts of polyphenolic antioxidants. The purpose of this study was to examine the anti-oxidative and anti-inflammation effects of combination of mixture of Eckloina cava extrat and scoria with optimal ratio. Therefore, this study suggested that combination of mixture of Eckloina cava extrat and scoria and its attenuated the oxidative and inflammatory reactions.

Key Words: Scoria, Ecklonia cava, Anti-inflammation

\section{INTRODUCTION}

Scoria is found in large amounts in Jeju Island, as an adsorbent of heavy metal ions $\left(\left(\mathrm{Ni}_{2}+, \mathrm{Zn}_{2}+\right.\right.$, and $\left.\mathrm{Cr}_{3}+\right)$ in an aspect of its efficient utilization. "scoria" is a volcanic stone made as clay burns due to high heat caused by volcanic activity, and thus is also known as a kind of natural ceramics. Scoria is found at Jeju-do, Korea, and referred to as "Song-I" as Jeju island dialect. It has been known that scoria contains a large amount of natural minerals, and thus has its own excellent physical properties such as a high far-infrared radiation rate, antibacterial activity, and deodorization capacity (Jeon et al., 2018). Marine plants have emerged as a potential resource of bioactive compounds for the development of cosmeceutical ingredients (Kiuru et al., 2014). Marine algae such as Ecklonia cava, it have been shown to inhibit cellular melanin synthesis in murine melanoma B16/F10 cells (Heo et al., 2010; Cha et al., 2011). The purpose of combination of mixture of Eckloina cava extrat and scoria (SE mixtures) were determined the optimal ratio to increase Eckloina cava extrat and scoria efficacy without cellular toxicity.

\section{MATERIALS AND METHODS}

Scoria used $400 \mathrm{~nm} \sim 20 \mu \mathrm{m}$ sphere by processing wet dry method. The radical scavenging activity of SE mixtures was measured using a stable radical 2, 2-diphenyl-1-picrylhydrazyl (DPPH, Sigma-Aldrich, St. Louis, MO, USA). The scavenging effects were evaluated by employing a reaction mixture constituted with aliquots of the SD mixtures and a

Received: July 11, 2018 / Accepted: October 22, 2018

*Professor.

${ }^{\dagger}$ Corresponding author: Hyun Kang. Department of Medical Laboratory Science, College of Health Science, Dankook University, Cheonan-si, Chungnam 31116, Korea.

Tel: +82-41-550-3015, Fax: +82-41-559-7934, e-mail: hkang@dankook.ac.kr

(C) The Korean Society for Biomedical Laboratory Sciences. All rights reserved.

(c) This is an Open Access article distributed under the terms of the Creative Commons Attribution Non-Commercial License (http://creativecommons.org/licenses/by-nc/3.0/) which permits unrestricted non-commercial use, distribution, and reproduction in any medium, provided the original work is properly cited. 
DPPH methanolic solution as described previously (Nanjo et al., 1996). Briefly, a sample solution of $60 \mu \mathrm{L}$ of each SD mixtures, was added to $60 \mu \mathrm{L}$ of DPPH $(60 \mu \mathrm{M})$ in methanol. After mixing vigorously for $10 \mathrm{~s}$, the mixture was then transferred into a $100 \mu \mathrm{L}$ Teflon capillary tube and the scavenging activity of each sample on DPPH radical was measured using a JES-FA ESR spectrometer (Jeol Ltd, Tokyo, Japan). A spin adduct was measured on an ESR spectrometer exactly after 2 min. Experimental conditions were as follows: central field, 3,475 G; modulation frequency, $100 \mathrm{kHz}$; modulation amplitude, $2 \mathrm{G}$; microwave power, $5 \mathrm{~mW}$; gain, $6.3 \times 105$, and temperature, $298 \mathrm{~K}$. BV-2 microglia cells were cultured at $37^{\circ} \mathrm{C}$ in $5 \% \mathrm{CO}_{2}$ in DMEM (Invitrogen, Carlsbad, CA, USA) supplemented with 5\% FBS (Hyclone, Logan, UT, USA) and antibiotics (Invitrogen). For viability assay, 3-(4, 5-dimethylthiazol-2-yl)-2, 5-diphenyl-tetrazolium bromide (MTT, Sigma-Aldrich, St. Louis, MO, USA) assay was used as described previously (Kim et al., 2011). Briefly, BV-2 cells were plated onto 96 well plates and exposed to SD mixtures. MTT was added to each well then incubated for additional $2 \mathrm{~h}$ in the dark at $37^{\circ} \mathrm{C}$. The medium was then aspirated from the wells and the blue formazan product obtained was dissolved in DMSO. The plates were analyzed at $570 \mathrm{~nm}$ using a microplate reader (Tecan Trading AG, Switzerland). Each experiment was conducted in triplicate. Cell viability (\%) was calculated as the ratio of the absorbance of sample to that of the non-treated sample, expressed as a percentage. In all other experiments, the cells were pretreated with SE mixtures at indicated concentrations for $1 \mathrm{~h}$ before the addition of LPS $(1 \mu \mathrm{g} / \mathrm{mL}$, Sigma-Aldrich, St Louis, MO, USA) in serum free DMEM. An equal volume of sterile water was added to all control treatments. Production of NO was assayed by measuring the levels of nitrite in the culture supernatant using colorimetric assay with Griess reagent (Green et al., 1982). Briefly, BV-2 cells $\left(2 \times 10^{5}\right.$ cells $/ \mathrm{mL}$ ) were seeded in 6-well plates in $500 \mu \mathrm{L}$ complete culture medium and treated with the SE mixtures at indicated concentrations for $1 \mathrm{~h}$ prior to stimulation with LPS $(1 \mu \mathrm{g} /$ $\mathrm{mL})$ for $2 \mathrm{~h}$. Culture supernatant $(50 \mu \mathrm{L})$ was reacted with an equal volume of Griess reagent $(0.1 \%$ naphthylethylenediamine and $1 \%$ sulfanilamide in $5 \% \mathrm{H}_{3} \mathrm{PO}_{4}$ ) in 96-well plates at room temperature in the dark. Nitrite concentrations

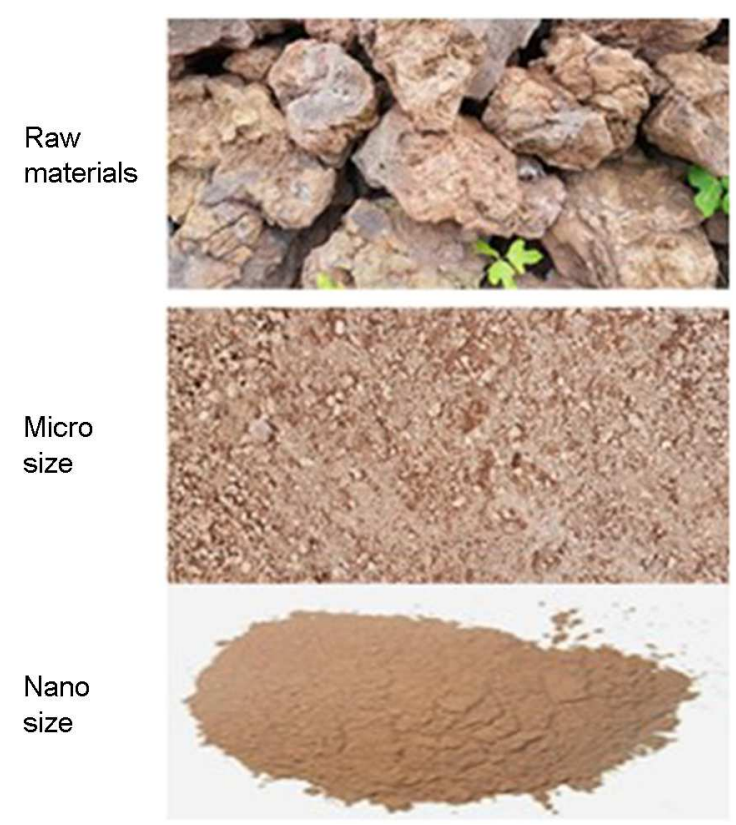

Fig. 1. Jeju' scoria raw materials (upper panel), micro size (middle panel, 2 $20 \mu \mathrm{m}$ ), and nano size (lower panel, 400 800 nm).

were determined by using standard solutions of sodium nitrite prepared in the culture medium. The absorbance was determined at $540 \mathrm{~nm}$ using a microplate reader (Tecan). BV-2 microglia cells $\left(1 \times 10^{5}\right.$ cells/well $)$ were cultured in 96 well plates and treated with the SD mixtures at the indicated concentrations for $1 \mathrm{~h}$ and stimulated with LPS $(1 \mu \mathrm{g}$ $/ \mathrm{mL})$. At $4 \mathrm{~h}$ post LPS treatment, the cells were collected and the supernatants were evaluated for IL-6 contents using a murine IL-6 ELISA kit from BD Biosciences, respectively (San Jose, CA, USA) according to the manufacturer's instructions. All data are represented as the mean \pm S.E.M of at least three independent experiments. Statistical analyses were performed using SAS statistical software (SAS Institute, Cray, NC, USA) using one-way analysis of variance, followed by Dunnett's multiple range tests. $P$ value $<0.05$ was considered statistically significant.

\section{RESULTS AND DISCUSSION}

Scoria includes volcanic ashes, volcanic gravel, volcanic rock, and volcanic boms (Fig. 1). Scoria perhaps tends to be highly usable for various beauty materials such as skin moistu- 
Table 1. The combination ratio of Jeju' Ecklonia cava and scoria

\begin{tabular}{ccc}
\hline \hline No. & Ecklonia cava & Scoria \\
\hline 1 & 10 & 0 \\
2 & 9 & 1 \\
3 & 8 & 2 \\
4 & 7 & 3 \\
5 & 6 & 4 \\
6 & 5 & 5 \\
7 & 4 & 6 \\
8 & 3 & 7 \\
9 & 2 & 8 \\
10 & 1 & 9 \\
11 & 0 & 10 \\
\hline
\end{tabular}

rizing, pore tightening, cleansing, anti-microbial activity. Scoria having a high content of silicon oxide, aluminum oxide, titanium, and iron oxide. In addition scoria contain various minerals such as calcium oxide, magnesium oxide, potassium oxide, and sodium oxide (Jeon et al., 2018). Scoria has physical properties: it has a alkine $\mathrm{pH}$ of appromximately 7.2 7.8, and various colors depending on the mineral component generally contained vesicular structure. E. cava is a brown alga found in the coastal area of Korea and Japan, and has been used as food and traditional medicine (Wijesinghe et al., 2012). It is a rich source of phlorotannins and fucoidans that possesses a wide range of biological activities (Kim et al., 2006). Phlorotannins are produced by the polymerization of phloroglucinol and are found only in marine brown algae. E. cava contains various phlorotannins, such as eckol, dieckol, 6,6'-bieckol, eckstolonol, and triphlorethol-A. (Li et al., 2006). The biological effects of $E$. cava identified so far include antioxidant, antiinflammatory, antibacterial, antidiabetic, and anticancer activities (Kang et al., 2010; Lee et al., 2011). As shown in Fig. 2, SE mixtures showed significant DPPH radical scavenging activity. The maximum scavenging activity was observed at SE mixture 2 and 3 of concentration $(P<0.001)$. As shown in Fig. 3, treatment with LPS $(1 \mu \mathrm{g} / \mathrm{mL})$ with or without, SE mixtures 6, 7, 8, 9, 10 and 11 concentrations did affect the cell viability. However, SE mixtures 1, 2, 3, 4, and 5 did not exhibit any cytotoxicity on BV-2 microglia cells.

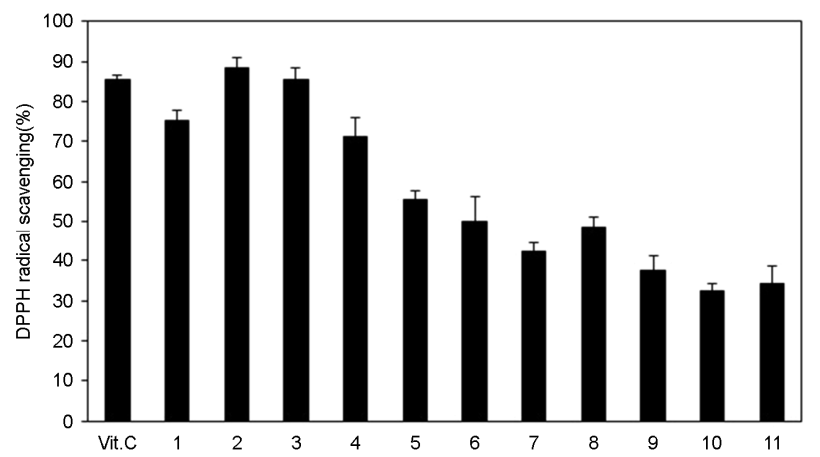

Fig. 2. Effects of combination of mixture of Eckloina cava extrat and scoria (SE mixture) on DPPH radical scavenging activity. The capacity to scavenge DPPH free radical by $100 \mu \mathrm{g} / \mathrm{mL}$ concentration was measured. The scavenging activity of each sample on DPPH radical was measured using a JES-FA ESR spectrometer. A spin adduct was measured on an ESR spectrometer exactly 2 min later.

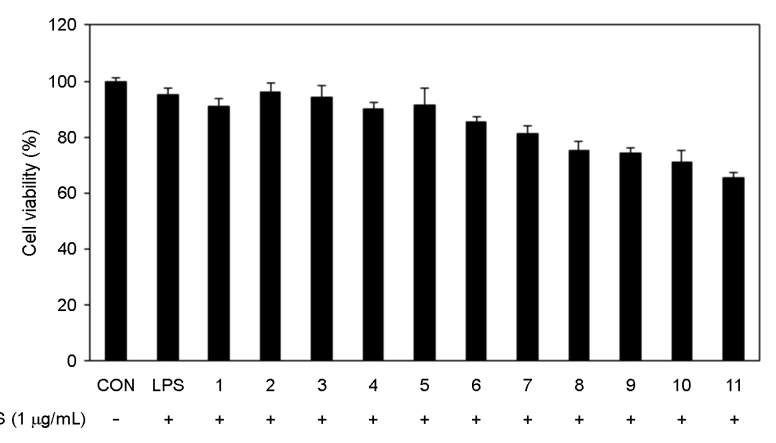

Fig. 3. Effects of combination of mixture of Eckloina cava extract and scoria (SE mixture) on the viability of BV-2 microglial cells. Cell viability in combination of Eckloina cava extract and scoria $(100 \mu \mathrm{g} / \mathrm{mL})$ treated cells was determined using MTT assay. The results are displayed in percentage of control samples.

NO is one of the important inflammatory mediators produced by activated microglia. To study the effect of SE mixture on LPS-stimulated NO release, BV-2 microglia were treated with a series of mixture for $30 \mathrm{~min}$ prior to LPS $(1 \mu \mathrm{g} / \mathrm{mL})$ stimulation for $4 \mathrm{~h}$. NO production by LPS-activated cells was found to be significantly inhibited by SE mixture extract in a concentration-dependent manner (Fig. 4). It stimulates cellular reactive oxygen (ROS) production (Bedard et al., 2007; Lassegue and Griendling, 2010; Cho et al., 2014) and the expression of inflammatory cytokines such as TNF- $\alpha$ and IL-1 (Fujii et al., 2002; Bengalli et al., 2013). As shown in Fig. 5, IL-6 levels were increased significantly after LPS 


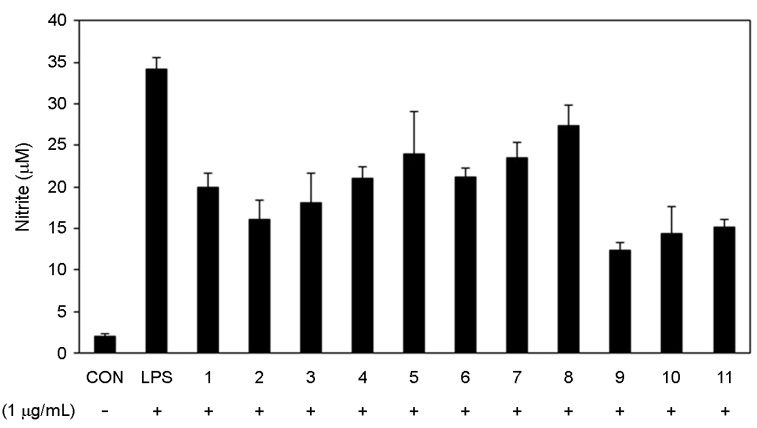

Fig. 4. Effects of combination of mixture of Eckloina cava extract and scoria (SE mixture) on NO Production in LPS-stimulated BV-2 microglial cells. BV-2 cells were treated with combination of Eckloina cava extract and scoria at $100 \mu \mathrm{g} / \mathrm{mL}$ concentrations with or without LPS $(1 \mu \mathrm{g} / \mathrm{mL})$ for $24 \mathrm{~h}$. The nitrite in the culture supernatant was evaluated using Griess reagent.

treatment $(1 \mu \mathrm{g} / \mathrm{mL})$ when compared to those in untreated cells $(P<0.001)$. SE mixtures 6, 7, 8, 9, 10 and 11 significantly inhibited these pro-inflammatory cytokines in LPSstimulated BV-2 cells. In the present study, it was confirmed that lipopolysaccaharide (LPS) increased the gene expression of the inflammatory cytokines IL-6 (Fig. 5). In addition, the LPS-induced cytokine expression was perhaps attenuated by dieckol and eckol. Dieckol is a dimeric form of eckol. SE mixtures 2 and 3 contained Eckloina cava extrat and scoria were 9:1 and 8:2, respectively. These SE mixtures were showed the optimal ratio ratio of biological activities without cellular toxicity. Further studies are needed to validate the anti-oxidative and anti-inflammatory mechanisms.

\section{ACKNOWLEDGEMENT}

None.

\section{CONFLICTS OF INTEREST}

The authors declare that there is no conflict of interests regarding the publication this articles.

\section{REFERENCES}

Bedard K, Krause KH. The NOX family of ROS-generating NADPH oxidases: physiology and pathophysiology. Physiol Rev. 2007. 87: 245-313.

Bengalli R, Molteni E, Longhin E, Refsnes M, Camatini M,

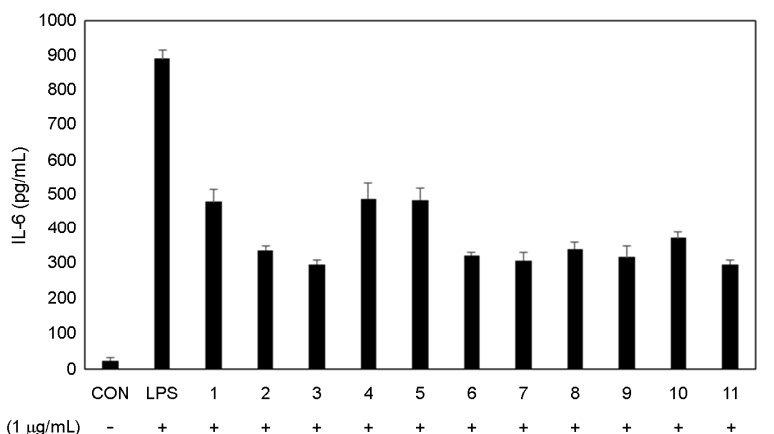

Fig. 5. Effect of mixture of Eckloina cava extrat and scoria (SE mixture) on pro-inflammatory cytokine IL-6 production in LPSstimulated BV-2 cells. BV-2 cells were treated with of mixture of Eckloina cava extrat and scoria at indicated concentrations with or without LPS $(1 \mu \mathrm{g} / \mathrm{mL})$ for $4 \mathrm{~h}$. The IL-6 in the culture supernatant was evaluated using a murine IL-6 ELISA kits, respectively, from BD Sciences according to the manufacturer's instruction. Data are presented as the mean \pm SEM $(n=3)$ for three independent experiments. $\# P<0.001$, when compared with control group; $* P<$ 0.05 , $* * P<0.01, * * * P<0.001$, compared with LPS alone treated group by one-way analysis of variance, followed by Dunnett's multiple range tests.

Gualtieri M. Release of IL-1 beta triggered by Milan summer PM10: molecular pathways involved in the cytokine release. Biomed Res Int. 2013. 158093.

Cha SH, Ko SC, Kim D, Jeon YJ. Screening of marine algae for potential tyrosinase inhibitor: those inhibitors reduced tyrosinase activity and melanin synthesis in zebrafish. J Dermatol. 2011. 38: 354-363.

Cho DY, Le W, Bravo DT, Hwang PH, Illek B, Fischer H, Nayak JV. Air pollutants cause release of hydrogen peroxide and interleukin-8 in a human primary nasal tissue culture model. Int Forum Allergy Rhinol. 2014. 4: 966-971.

Choi JG, Kang OH, Brice OO, Lee YS, Chae HS, Oh YC, Sohn DH, Park H, Choi HG, Kim SG, Shin DW, Kwon DY. Antibacterial activity of Ecklonia cava against methicillin-resistant Staphylococcus aureus and Salmonella spp. Foodborne Pathog Dis. 2010. 7: 435-441.

Jeon HY, Jung HJ, SHIN JS, An SA, Kang BY. Mousse-type cosmetic composition containing scoria. US patent application. 2018. 006217.

Fujii T, Hayashi S, Hogg JC, Mukae H, Suwa T, Goto Y, Vincent $\mathrm{R}$, van Eeden SF. Interaction of alveolar macrophages and airway epithelial cells following exposure to particulate matter produces mediators that stimulate the bone marrow. Am J Respir Cell Mol Biol. 2002. 27: 34-41. 
Green LC, Wagner DA, Glogowski J, Skipper PL, Wishnok JS, Tannenbaum SR. Analysis of nitrate, nitrite, and [15N] nitrite in biological fluids. Anal Biochem. 1982. 126: 131-138.

Heo SJ, Ko SC, Kang SM, Cha SH, Lee SH, Kang DH, Jung WK, Affan A, Oh C, Jeon YJ. Inhibitory effect of diphlorethohydroxycarmalol on melanogenesis and its protective effect against UV-B radiation-induced cell damage. Food Chem Toxicol. 2010. 48: 1355-1361.

Kang C, Jin YB, Lee H, Cha M, Sohn ET, Moon J, Park C, Chun S, Jung ES, Hong JS, Kim SB, Kim JS, Kim E. Brown alga Ecklonia cava attenuates type 1diabetes by activating AMPK and Akt signaling pathways. Food Chem Toxicol. 2010. 48: 509-516.

Kim BW, Koppula S, Kim IS, Lim HW. Anti-neuroinflammatory activity of Kamebakaurin from Isodon japonicus via inhibition of c-Jun NH-terminal kinase and p38 mitogen-activated protein kinase pathway in activated microglial cells. J Pharmacol Sci. 2011. 116: 296-308.

Kim MM, Ta QV, Mendis E, Rajapakse N, Jung WK, Byun HG, Jeon YJ, Kim SK. Phlorotannins in Ecklonia cava extract inhibit matrix metalloproteinase activity. Life Sci. 2006. 79; 1436-1443.

Kiuru P, D'Auria MV, Muller CD, Tammela P, Vuorela H, YliKauhaluoma J. Exploring marine resources for bioactive compounds. Planta Med. 2014. 80: 1234-1246.

Lassegue B, Griendling KK. NADPH oxidases: functions and pathologies in the vasculature. Arterioscler Thromb Vasc Biol. 2010. 30: 653-661.

Lee H, Kang C, Jung ES, Kim JS, Kim E. Antimetastatic activity of polyphenol-rich extract of Ecklonia cava through the inhibition of the Akt pathway in A549 human lung cancer cells. Food Chem. 2011. 127: 1229-1236.

Li Y, Qian ZJ, Ryu B, Lee SH, Kim MM, Kim SK. Chemical components and its antioxidant properties in vitro: an edible marine brown alga, Ecklonia cava. Bioorg Med Chem. 2009. 17: 1963-1973.

Nanjo F, Goto K, Seto R, Suzuki M. Scavenging effects of tea catechins and their derivatives on 1,1-diphenyl-2-picrylhydrazyl radical. Free Radic Biol Med. 1996. 21: 895-902.

Wijesinghe WA, Jeon YJ. Exploiting biological activities of brown seaweed Ecklonia cava for potential industrial applications: a review. Int J Food Sci Nutr. 2012. 63: 225-235.

https://doi.org/10.15616/BSL.2018.24.4.329

Cite this article as: Kang H. Effect of Mixture Composed of Jeju' Scoria and Ecklonia cava on Antiinflammation. Biomedical Science Letters. 2018. 24: 329-333. 